\title{
DIVERSIDADE FUNCIONAL DA COMUNIDADE ZOOPLANCTÔNICA NA BACIA HIDROGRÁFICA DO RIO DOS FRADES, BA
}

\author{
AUTOR: ESCARLETT DE ARRUDA RAMOS \\ CO-AUTOR/ORIENTADOR: NADSON RESSYE SIMOES DA SILVA
}

\begin{abstract}
Resumo: A bacia do Rio dos Frades apresenta um papel fundamental nos serviços ecossistêmicos e na diversidade ecológica do Extremo Sul da Bahia. Nesse sistema, a presença de invertebrados zooplanctônicos funciona como indicador das condições ambientais. O objetivo deste estudo foi analisar a variação espacial da diversidade funcional da comunidade zooplanctônica no Rio dos Frades. As coletas das amostras foram realizadas nos meses de Agosto de 2018, Abril de 2019, Julho de 2019 e em Novembro de 2019. Os organismos foram identificados utilizando microscópio estereoscópio e microscópio óptico e auxílio da bibliografia especializada. Foram identificadas 45 espécies de cladóceros e copépodes. Os resultados de riqueza funcional variaram de 2.7×10-7 a $2.98 \times 10-2$; o índice de equitabilidade funcional variou entre 0,16 e 0.82; para a divergência funcional os dados foram entre 0,45 a 0,81 ; a dispersão funcional foi de 0,03 a 0,32. A análise de correspondência canônica indicou associação entre a estrutura da assembleia e variáveis ambientais ( $p$-valor 0,02 ), sendo que as variáveis mais importantes foram: clorofila-a e coliformes totais. Estes resultados sugerem que existe uma influência da região do Vale sobre assembleia de microcrustáceos alterando a qualidade da água e comunidade biótica entre montante e jusante da bacia.
\end{abstract}

Palavras-chave: Zooplâncton, Microinvertebrados, Bacia hidrográfica. 